\title{
Research on the Teaching Method System of Applied Undergraduate Colleges
}

\author{
Hongfeng Zhou ${ }^{1, a}$, Meng Chen ${ }^{1, b}$ and Zhe Xu $u^{1, c}$ \\ ${ }^{1}$ Jilin Teachers'Institute of Engineering and Technology, Changchun,Jilin , China \\ a229613446@qq.com,b1359233356@qq.com,,2042487349@qq.com
}

\section{Keywords: Applied undergraduate course; Specialized teaching method}

\begin{abstract}
This article mainly from the view of system, discusses the connotation and elements of the teaching method of applied undergraduate, according to the teaching characteristics of applied talents, from the analysis of different types of classes in a suitable teaching method, teaching situation, teaching methods and media.
\end{abstract}

\section{Introduction}

Local application of our country university training is the main technology of the production line of the talent, the "national long-term education reform and development plan (2010-2020)" pointed out that "to follow the two important rules: education laws and laws of human development; deepening the educational reform, innovation education teaching methods, through these training methods, can show a variety of produce, there is more, a galaxy of talents rise above the common herd innovative talents emerging situation".

The outline shows that the reform of education and teaching methods plays an extremely important role in the mode of personnel training. At the same time, it also proposes that the scale of training complex and applied talents will be expanded. But at present our country according to the teaching method of applied undergraduate talents only at the beginning stage, the main use of the teaching method of Applied Undergraduate Colleges and universities is still the traditional teaching method, the "teaching method" to occupy the dominant position. The teaching method has become the key and important problem of training applied undergraduate talents. Therefore, if we want to improve the teaching quality of application-oriented universities, we can only create teaching methods that conform to the training law of applied talents.

\section{Concept definition and related factors analysis of Applied Undergraduate Teaching Methodology}

Application undergraduate teaching method concept definition. Applied undergraduate education is to adapt to and meet the needs of taking a new road to industrialization in China directly for production, construction, management, service and other first-line technical needs of practical education, the concept of teaching method to cultivate the scene to solve the problem of production, construction, management, service and other front-line teaching target is professional the main consideration, follow the teaching theory, suitable for the corresponding teaching media under the support of the professional teaching content and teaching methods, the overall characteristics of the object. The teaching method in teaching in the field of use cannot do without "with students", "how to professional teaching objectives"? "What professional teaching content"? "What application of teaching media and so on these teaching elements.

\section{Relevant elements and analysis of Applied Undergraduate Teaching Methods.}

The teaching method of applied undergraduate application oriented undergraduate technical control system, from the perspective of teaching system to teaching of elements of integration and analysis, according to the concept of system consulting (analysis and analysis of characteristics of Students Occupation Expectation (post), training objectives), controller (teaching methods), executive mechanism (teaching content and teaching materials), technology (teaching media and teaching environment) control objects (students) and feedback (evaluation) to construct professional teaching elements. 


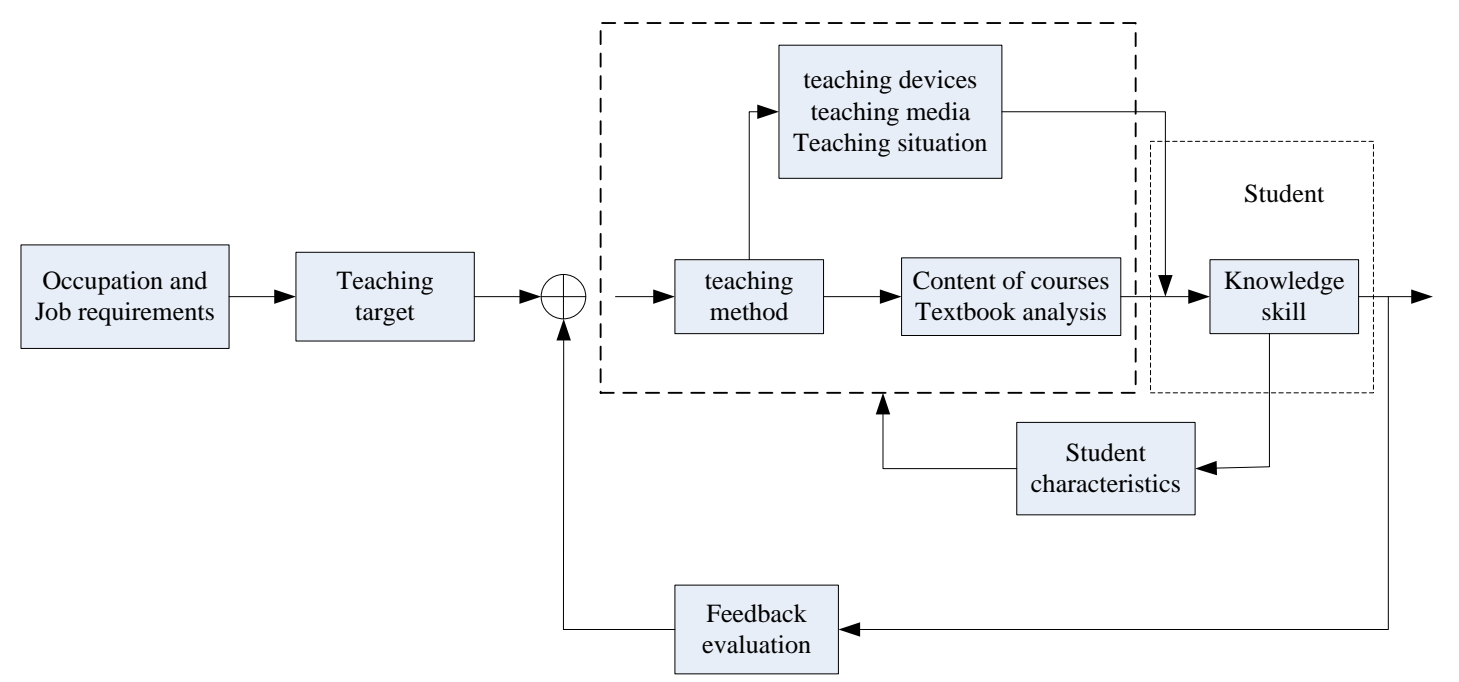

Figure 1.

Component diagram of specialized teaching method

based on system view

Can be seen from Figure 1, the graph is a type of application of double feedback undergraduate teaching system, teaching system for the quantitative means of applied undergraduate education as the main teaching objectives, guide teachers in teaching content analysis, teaching materials (executive body) basis, have to master the proper teaching methods (the optimized controller) to implement teaching strategies and teaching methods, teaching situation through ((technology and method) and teaching media to specific teaching activities, as the control object (students), through the good teaching to get knowledge and skills, to be able to meet the needs of present and future occupation, and to improve their own quality, to meet the requirements of the future society.

The structure model is designed by using systematic method. The main emphasis is not on the order relation of each teaching element, but on the function relation. Can be seen from Figure 1, the model is a double feedback teaching system, including professional and the teaching goal is the typical occupation activities in the corresponding professional work ability oriented, teachers as the main guide, based on the analysis of the teaching contents, through appropriate teaching methods to implement professional the teaching strategy, and through the teaching means, teaching media and teaching situation of specific teaching activities, as students, through the teaching of good behavior, be able to adapt to present and future occupation need knowledge and ability, and improve their own quality. Through feedback to detect whether the initial target has been achieved, if not yet achieved, the process should be revised repeatedly until the desired teaching objectives have been achieved.

\section{Selection of Applied Undergraduate Teaching Methods}

According to different curriculum types and teaching characteristics, the applied undergraduate course system is systematically classified from the aspects of teaching methods, teaching media and teaching methods, and the teaching situation. The following are shown in table 1. For example, in favor of unit teaching to cultivate the students' quality, emotion and attitude, can choose the teaching method, role playing method; unit teaching tend to cultivate students comprehensive analytical ability, creative thinking training class, you can choose the method of brainstorming, case teaching method and project teaching method. 
Table 1 Selection and classification of teaching methods

\begin{tabular}{|c|c|c|c|c|c|}
\hline Course type & $\begin{array}{c}\text { Course } \\
\text { characteristi-c } \\
\text { cs }\end{array}$ & Course name & $\begin{array}{l}\text { teaching } \\
\text { method }\end{array}$ & $\begin{array}{l}\text { Teaching media } \\
\text { and means }\end{array}$ & Teaching situation \\
\hline $\begin{array}{l}\text { Theoretical } \\
\text { knowledge }\end{array}$ & $\begin{array}{l}\text { The teaching } \\
\text { objective } \\
\text { emphasizes } \\
\text { the } \\
\text { acceptance of } \\
\text { knowledge }\end{array}$ & $\begin{array}{l}\text { Circuits, analog } \\
\text { electronics, } \\
\text { digital } \\
\text { electronics, } \\
\text { automatic control } \\
\text { principles, modern } \\
\text { control theory, etc. }\end{array}$ & $\begin{array}{l}\text { Guided text } \\
\text { teaching } \\
\text { method, } \\
\text { posting board } \\
\text { teaching } \\
\text { method, mind } \\
\text { mapping } \\
\text { teaching } \\
\text { method, case } \\
\text { teaching } \\
\text { method and } \\
\text { so on }\end{array}$ & $\begin{array}{l}\text { Language } \\
\text { expression, } \\
\text { picture writing, } \\
\text { electronic } \\
\text { teaching plan, } \\
\text { teaching aids } \\
\text { demonstration, } \\
\text { animation } \\
\text { simulation, } \\
\text { projection, video } \\
\text { recording }\end{array}$ & $\begin{array}{l}\text { The creation of } \\
\text { situational interest, } \\
\text { stimulate creative } \\
\text { consciousness; } \\
\text { Create problem } \\
\text { situations and guide } \\
\text { active exploration and } \\
\text { thinking; }\end{array}$ \\
\hline Motor skills & $\begin{array}{l}\text { Take students' } \\
\text { mastery of } \\
\text { motor skills } \\
\text { as the main } \\
\text { teaching } \\
\text { objective }\end{array}$ & $\begin{array}{l}\text { SCM principle and } \\
\text { application, PLC } \\
\text { and application, } \\
\text { electrical skills } \\
\text { training, electronic } \\
\text { technology } \\
\text { curriculum design, } \\
\text { etc. }\end{array}$ & $\begin{array}{l}\text { Experiment } \\
\text { teaching } \\
\text { method, four } \\
\text { stage teaching } \\
\text { method and } \\
\text { technical } \\
\text { experiment } \\
\text { teaching } \\
\text { method }\end{array}$ & $\begin{array}{l}\text { Demonstration of } \\
\text { action, } \\
\text { demonstration of } \\
\text { results and } \\
\text { exploration of } \\
\text { experiment }\end{array}$ & $\begin{array}{l}\text { Creating practice } \\
\text { situation, emphasizing } \\
\text { imitation, } \\
\text { summarization and } \\
\text { thinking; }\end{array}$ \\
\hline $\begin{array}{l}\text { Quality cultivation } \\
\text { category }\end{array}$ & $\begin{array}{l}\text { Unit teaching } \\
\text { in developing } \\
\text { students' } \\
\text { quality, } \\
\text { emotion and } \\
\text { attitude }\end{array}$ & $\begin{array}{l}\text { Ideological and } \\
\text { moral cultivation } \\
\text { and legal basis, } \\
\text { Mao Deng and the } \\
\text { "Three } \\
\text { Represents", career } \\
\text { development and } \\
\text { employment } \\
\text { guidance }\end{array}$ & $\begin{array}{l}\text { Teaching } \\
\text { method and } \\
\text { role playing } \\
\text { method }\end{array}$ & $\begin{array}{l}\text { Language } \\
\text { expression, } \\
\text { picture writing, } \\
\text { electronic } \\
\text { teaching plan, } \\
\text { teaching aids } \\
\text { demonstration, } \\
\text { animation } \\
\text { simulation, } \\
\text { projection, video } \\
\text { recording }\end{array}$ & $\begin{array}{l}\text { Creating professional } \\
\text { situation } \\
\text { stimulating and } \\
\text { consciousness; role } \\
\text { Create problem } \\
\text { situations and guide } \\
\text { active exploration and } \\
\text { thinking; }\end{array}$ \\
\hline $\begin{array}{l}\text { Engineering } \\
\text { application class }\end{array}$ & $\begin{array}{l}\text { It is inclined } \\
\text { to train } \\
\text { students' } \\
\text { comprehensiv } \\
\text { e analysis } \\
\text { ability and } \\
\text { train creative } \\
\text { thinking class }\end{array}$ & $\begin{array}{l}\text { Process control } \\
\text { system design, } \\
\text { motion control } \\
\text { system design and } \\
\text { debugging, } \\
\text { integrated } \\
\text { curriculum design, } \\
\text { graduation design }\end{array}$ & $\begin{array}{l}\text { Brainstormin } \\
\mathrm{g}, \quad \text { case } \\
\text { teaching } \\
\text { method, } \\
\text { project } \\
\text { teaching } \\
\text { method }\end{array}$ & $\begin{array}{l}\text { Student } \quad \text { work } \\
\text { sheet, guide } \\
\text { book, study } \\
\text { guide book, } \\
\text { industry } \\
\text { specification, } \\
\text { professional } \\
\text { standard, } \\
\text { engineering } \\
\text { document sample }\end{array}$ & $\begin{array}{l}\begin{array}{l}\text { Create a discussion } \\
\text { situation, }\end{array} \\
\text { innovative atmosphere } \\
\text { and cooperation spirit; } \\
\text { Create a professional } \\
\text { situation, develop a } \\
\text { rigorous engineering } \\
\text { design attitude, and } \\
\text { expand the multi } \\
\text { thinking. }\end{array}$ \\
\hline
\end{tabular}




\section{References}

[1]N.G. Hong, et al. Conception of Undergraduate Training Program for Applied Undergraduate Majors. Journal of East China Institute of Metallurgy. 1999, (1)

[2]D.Y. Huang, Misunderstanding and Countermeasures of "Double Qualified Teachers" Construction in Higher Vocational Colleges [J]. Educational Exploration. 2006 (12)

[3]X.C. Zhu, Practical Talents Training in Applied Undergraduate Course. Modern Educational Equipment in China. 2004, (9)

[4]B.Z. Tang, A Brief Analysis of the Characteristics of Vocational and Technical Teachers' Training in Higher Vocational Education. Journal of Hebei Normal University. 1998, (1)

[5]Summer, wu yue-hong xu. Generation logic and value implication of the applied university league based on the analysis of the transformation of ordinary undergraduate course colleges and universities development perspective [J]. Journal of modern university education. 2015 (6)

[6]Wang sj, jing-wen wen, Hu Dan. Social transformation and applied colleges thinking of the construction of the modern university system [J]. Modern education management. 2015 (7)

[7]Huang ying,Gui-lin li, LeiJing,introduction to the micro-standard method application in the practice teaching $[\mathrm{J}]$. China's electricity education,2010 (01)

[8] Guohuang Liu,of college students from the teachers' professional development analysis [J]. Journal of chengdu university (education sciences), 2009 (01)

[9] L.Lin,Q.M.Yao and S.L.Lu. The Reform and Implementation of Talent Training Mode for Vocational Teachers -- Taking the Excellent Vocational Teacher Training Program as An Example, [J]. Vocational and Technical Education, 2012 (35): 65-68.(In Chinese)

[10]L.Xu. Study on Professional Teaching Methods in German Vocational Schools [D]. Tianjin: Tianjin University,.2009.(In Chinese) 